\title{
A Relational Approach to Rationing in a Time of Pandemic
}

\author{
Luís Cordeiro-Rodrigues $^{1} \mathbb{D} \cdot$ Cornelius Ewuoso $^{2}$
}

Accepted: 24 October 2020 / Published online: 23 January 2021

(c) Springer Nature B.V. 2021

\section{Introduction}

The COVID-19 pandemic has significantly impacted various healthcare systems across the world. Most countries were not prepared for such a demand for medical supplies, obligating many health professionals into difficult ethical decisions about rationing these resources. Decisions about how to allocate medical resources in situations of scarcity are both emotionally and ethically challenging. Across the world, various bioethical committees have provided guidelines on how to decide whom to save in such circumstances. ${ }^{1}$ The majority of theories and practices of rationing are life-based approaches. ${ }^{2}$ Examples include natural lifespan, fair innings and complete lives egalitarianism; such theories tend to prescribe that saving the young, those ones with the health condition that means they are most likely to survive, and to save the highest number of lives ought to be the focus of rationing decisions. ${ }^{3}$

In this article, we wish to offer a different perspective, one that not only relies on a distinct ethical theory, but also has different implications from the theories on rationing previously considered. We address, from an African relational point of

\footnotetext{
${ }^{1}$ Singh JA, Moodley K. "Critical care triaging in the shadow of COVID-19: Ethics considerations", South African Medical Journal 110 (2020): 355-359.

${ }^{2}$ A life-based approach (to rationing) is an approach which - from a utilitarian perspective - emphasizes saving more life years, and from an egalitarian perspective, argues for the equal opportunity of individuals to experience the life-cycles typical of a human life.

${ }^{3}$ Frolic A, Kata A, Kraus P. "Development of a critical care triage protocol for pandemic influenza: integrating ethics, evidence and effectiveness", Healthcare quarterly 12 (2009): 54-62; Christian MD, Hawryluck L, Wax RS, et al. "Development of a triage protocol for critical care during an influenza pandemic", CMAJ: Canadian Medical Association journal=journal de l'Association medicale canadienne 175 (2006): 1377-1381; Powell T, Christ KC, Birkhead GS. "Allocation of ventilators in a public health disaster", Disaster medicine and public health preparedness 2 (2008): 20-26.
}

Luís Cordeiro-Rodrigues

Lccmr1984@gmail.com

Cornelius Ewuoso

ewuosocornelius@yahoo.com

1 Department of Philosophy, Yuelu Academy, Hunan University, Changsha, China

2 Department of Medicine, Faculty of Health Sciences, University of Cape Town, Cape Town, South Africa 
view, the question of who ought to be given priority to receive medical treatment in the context of a pandemic with scarce resources, such as the one we are currently facing with COVID-19. The relational approach is one that evaluates moral standing and the morality of actions according to relational properties and, particularly, relational properties to promote social harmony (defined below as the combination of good-will and identity). In other words, this is a perspective that considers that the way one relates to others is what counts the most in moral assessments of actions and moral status. Thus, according to this view, entities may have different degrees of moral status, including full, partial or no moral status. Taking this on board, we present reasons to think that decisions on rationing ought to be made based on whether these individuals would be instrumental in promoting social harmony and also in terms of whether they have full or partial moral status. Put differently, the relational properties individuals may have and the actions they take to promote social harmony are the criterion for rationing decisions.

We show that this theory is intuitively plausible and entails that it is not necessarily the case that the young, the prospectively healthy, or the many, should be given priority. Instead, age, health, and the number of saved lives, albeit morally relevant factors, are of secondary importance in relation to the factors we defend. Although we use the case study of COVID-19, the theory would be useful not just for future pandemics, which are likely to happen, but also for other situations of rationing and decisions about life and death (like in wars).

This approach is different from previous work, not only because it uses a relational theoretical perspective to address rationing and so has different implications, but also because it confronts a utilitarian and life-based approach to rationing with issues that have not yet been discussed at length. ${ }^{4}$ In particular, we offer thought experiments that we believe challenge the plausibility of these views and instead suggest that a relational perspective on rationing is preferred or at least merits consideration. On top of this, our work differs from previous research carried out into African bioethics and focusing on distributive justice in healthcare. ${ }^{5}$ This is because we apply African-inspired distributive patterns to rationing in a pandemic situation for the first time.

To carry out this task, we have divided this article into five sections. In section 1, we briefly explain the moral dilemmas faced in a pandemic like COVID-19. In the second section, we outline the moral theory that will serve as guidance for our arguments about rationing and suggest it is prima facie attractive. In section 3 , we tease out the implications of our relational moral theory to the rationing of health

\footnotetext{
${ }^{4}$ Frolic A, Kata A, Kraus P. "Development of a critical care triage protocol for pandemic influenza: integrating ethics, evidence and effectiveness", Healthcare quarterly 12 (2009): 54-62; Christian MD, Hawryluck L, Wax RS, et al. "Development of a triage protocol for critical care during an influenza pandemic", CMAJ: Canadian Medical Association journal=journal de l'Association medicale canadienne 175 (2006): 1377-1381; Powell T, Christ KC, Birkhead GS. "Allocation of ventilators in a public health disaster", Disaster medicine and public health preparedness 2 (2008): 20-26.

5 Wareham CS. "Partiality and distributive justice in African bioethics", Theor Med Bioeth 38 (2017): 127-144; Metz T. "Ancillary care obligations in light of an African bioethic: from entrustment to communion", Theor Med Bioeth 38 (2017): 111-126.
} 
resource, explaining who and why certain groups ought to be prioritized to receive medical treatment. Sections 4 and 5 respond to possible objections to our theory. In section 4 , we respond to the objections that challenge the moral plausibility of our argument, suggesting that alternative theories of rationing ought to be preferred. In section 5, we reply to those objections that contend that our approach leads to the violation of privacy, is impracticable and facilitates authoritarianism.

We classify the theory as 'African' and 'Afro-communitarian' and given that the meaning of the terms are disputed, we ought to here justify and clarify this use of terminology. The use of terms such as 'African' and 'Afro-communitarianism' have been widely contested and some scholars may contend that the version of AfroCommunitarianism we use, a Metzian interpretation of African ethical systems, may not be classified as such. ${ }^{6}$ We understand Afro-Communitarianism here as the ethical perspective that places the community as the main, or at least a leading source of value and does so based on intuitions, theories and concepts that hails from the African continent. ${ }^{7}$ Given this definition, out theory is Afro-communitarian to the extent that we use ideas that have been salient in African and, particularly, in the Afro-communitarian school of thought. In other words, the properties of our theory are ones that are recurrent in the African continent or Afro-communitarian theorizing, in a way that has not been as used elsewhere. The perspective does not essentialize Africa or African thought, as it is not referring to the essences of Africa, but to tendencies that can be found in a certain African philosophical school. The use of the term in this way is, for example, supported by Kwame Gyekye, who contends that 'in many areas of thought we can discern features of the traditional life and thought of African peoples sufficiently common to constitute a legitimate and reasonable basis for the construction (or reconstruction) of a philosophical system that may properly be called African' ${ }^{8}$

The question may be whether the Metzian ethics where we inspire most of our arguments can be classified as a sub-field of Afro-communitarianism. ${ }^{9}$ In reply, note that our arguments prioritize the value of the community precisely using African concepts such as Ubuntu and taking into consideration the relational ethical

\footnotetext{
${ }^{6}$ Molefe M. "A critique of Thad Metz's African theory of moral status", South African Journal of Philosophy 36 (2017): 195-205; Bewaji JAI, Ramose MB. "The Bewaji, Van Binsbergen and Ramose debate onUbuntu", South African Journal of Philosophy 22 (2013): 378-415; Mangena F. "Ramose's Legacy and the Future of African Philosophy", Philosophia Africana 18 (2016): 53-65.

7 Etieyibo E, Chimakonan JO. "African Philosophy: Past, Present, and Future", Philosophia Africana 18 (2016): 1-7; Gyekye K. An Essay on African Philosophical Thought: The Akan Conceptual Scheme (Philadelphia: Temple University Press, 1995); Murove MF. "Ubuntu", Diogenes 59 (2012): 36-47.

${ }^{8}$ Gyekye K. Person and Community in African Thought (Washington D.C: Council for Research in Values and Philosophy Washington, DC, 1992); 1.Gyekye K. Person and Community in African Thought (Washington D.C: Council for Research in Values and Philosophy Washington, DC, 1992); Gyekye K. An Essay on African Philosophical Thought: The Akan Conceptual Scheme (Philadelphia: Temple University Press, 1995).

9 Note however that Metz is not a consequentialist, but a deontologist. Our argument is based on his philosophical anthropology, but he personally does not endorse the consequentialist principle we have defended here. The fact that we endorse a consequentialist version however makes our perspective closer to many other African accounts that prefer consequentialism over deontological approaches.
} 
approach, just as African philosophy often takes. On top of this, note how other African philosophers have supported similar perspectives to ours regarding both the interpretation of Ubuntu and the relational moral status. Regarding the interpretation of Ubuntu, consider the following remark by Muxe Nkondo:

If you [ask] ubuntu advocates and philosophers: What principles inform and organize your life? What do you live for... the answers would express commitment to the good of the community in which their identities were formed, and a need to experience their lives as bound up in that of their community. ${ }^{10}$

Or as remarked by Kwasi Wiredu "[t]here can be little doubt that traditional African society was communitarian unless it be a matter of exceptions that prove the rule....communalism is an embodiment of the values of traditional Africa." ${ }^{11}$ Segun Gbadegesin also asserts "Every member is expected to consider him/herself as integral part of the whole and to play an appropriate role towards achieving the good of all."12

With respect to the relationality of moral status, consider the following view of Mfutso-Bengo and Masiye, "to be, is to belong to each other: no man is an island... it is through human interaction, and not rejection and projection, that the [individual] will achieve his potential."13 Ifeanyi Menkiti, when describing how African theories usually conceive relationships, states that:

The African view of man denies that persons can be defined by focusing on this or that physical or psychological characteristic of the lone individual [that is, solely on this feature]....(I)n the African view it is the community which defines the person as person, not some isolated static quality of rationality, will, or memory. ${ }^{14}$

In addition, consider the common African maxim that "a person is a person through other persons", which implies that the underlying reason for humanness, personhood and morality is relational. ${ }^{15}$ These quotes and the fact that throughout the article we consistently use the terms according to African ethical systems suggests that our theory is Afro-communitarian. Africanness and Afro-comunitarianness, however, comes in degrees and may be determined by the extent in which each theory is informed by those features that are salient in these. Nevertheless, given

\footnotetext{
${ }_{10}$ Muxe Nkondo G. "Ubuntu as public policy in South Africa: A conceptual framework", International Journal of African Renaissance Studies - Multi-, Inter- and Transdisciplinarity 2 (2007): p. 91.

11 Wiredu K. "Social Philosophy in Postcolonial Africa: Some Preliminaries Concerning Communalism and Communitarianism", South African Journal of Philosophy 27 (2008): pp. 333-336.

12 Gbadegesin S. African Philosophy: Traditional Yoruba Philosophy and Contemporary African Realities (New York: Peter Lang, 1991: p. 65).

13 Mfutso-Bengo J, Masiye F. "Toward an African Ubuntu/Umunthu bioethics in Malawi in the context of globalization," In: Myser C, editor. Bioethics Around the Globe: Oxford University Press, 2011: p. 156).

14 Menkiti I. "Person and Community in African Traditional Thought," In: Wright R, editor. African Philosophy, an Introduction. 3rd (Lanham, MD: University Press of America, 1984: p. 171).

15 Ewuoso C, Hall S. "Core aspects of ubuntu: A systematic review", South African Journal of Bioethics and Law 12 (2019): 93-103.
} 
that our perspective shares with a significant number of Afro-communitarian authors these salient features, our theory can be plausibly be included as a stream of Afro-communitarian.

\section{Health Emergency and COVID-19}

COVID-19 first detected towards the end of 2019 was an unknown disease to humanity so far, albeit it is part of the family of already known virus, the RNA viruses, such as SARS and MERS. Nevertheless, the COVID-19 seems to be much more contagious than the previous ones, which lead to a much higher widespread of the virus. Consequently, on January 30, 2020, the World Health Organization (WHO) declared COVID-19 a public health emergency of international concern. The high numbers of infected people during a pandemic situation will tend to outstrip available resources such as personnel, ventilators, ICU beds, protective gear, and physicians' time. Most governments tend to have limited health resources and, broadly speaking, are not prepared to respond to a high demand for these resources, as has happened during this pandemic. Consequently, the rationing of resources has been necessary.

Existing shortages in medical resources in this COVID-19 pandemic have forced societies to confront issues of allocation. For example, the surge in COVID19 related cases in advanced economies like Italy, France, Spain, and the United States, to name but a few countries, has significantly strained their critical health services and necessitated previously unanticipated allocation of limited resources. The United States has about 160,000 ventilators in hospitals and about 12,700 in the National Strategic Stockpile (Glenza 2020. This is insufficient for the roughly $10 \%$ of total COVID-19 patients (2.5 million and rising as we write) who require these machines. Dialysis machines are also becoming scarce owing to the global rise in COVID-19 related complications. ${ }^{16}$ Difficult care triaging decisions must be made in order to distribute insufficient medical goods among the $60 \%$ of COVID19 patients who require inpatient care: from inpatient interventions to mechanical ventilation. ${ }^{17}$ Rationing of ICU beds, health personnel, and ventilators have become prominent features of health services in well-off countries severely affected by the pandemic.

Most triaging decisions in the context of a pandemic often assume the form of 'Sophie's Choice'. Particularly, within the context of a pandemic, one patient will likely die when another patient is prioritized. One has a right to enjoy the highest standard of physical and mental health, regardless of contributions towards broad social goals. This is usually considered an inalienable right. ${ }^{18}$ However, in

\footnotetext{
16 Glenza J. Who gets a ventilator? The "gut-wrenching" chioces facing US health workers. The Guardian. 2020 April 09, 2020.

17 Singh JA, Moodley K. "Critical care triaging in the shadow of COVID-19: Ethics considerations", South African Medical Journal 110 (2020): 355-359.

18 Pillay N. "Right to health and the Universal Declaration of Human Rights", Lancet 372 (2008): 20052006.
} 
large-scale health disasters, access to the resources required to enjoy good health is not always guaranteed. Additionally, maintaining a conventional care standard is highly improbable in such situations, and individuals will not be treated similarly. Loss of lives are potentially inescapable outcomes of allocation decisions during a pandemic. Fair procedures, and reasonably developed/applied principles are key in justifying the loss of values, denying beneficial care to individuals on the grounds of scarcity, and building an equitable health system.

\section{An Afro-Communitarian Moral Theory}

The relational approach defended here holds the view that relationships have moral significance, and are core in attributing rights and entitlements as well as prescribing ethical duties and responsibilities. Afro-communitarianism is the perspective that the highest good consists of relating positively to others. For example, Desmond Tutu affirms that "harmony, friendliness, community are great goods. Social harmony is for us the summum bonum - the greatest good. Anything that subverts or undermines this sought-after good is to be avoided like the plague." ${ }^{19}$ Mabovula expresses this strongly in the following remark: "[Afro-communitarianism] expresses the idea that a person's life is meaningful only if he or she lives in harmony with other people because an African person is an integral part of society." 20 Hence, the morality of an action is measured by whether or not it relates in the right way to other individuals. Routinely, social harmony between individuals (or relating positively to the community) is understood as the combination of two elements: identification and good-will. ${ }^{21}$ To identify with others means to behave, feel, and understand that others are beings with whom we share our lives and, indeed, are a continuation of ourselves. Thus, identification involves positive emotions, behavior and perception of other individuals, feeling, treating and understanding them as beings worthy of value, and with whom we enjoy a sense of togetherness and act in ways to further this. Good-will involves behaving and feeling in ways that forward the well-being and excellence of other individuals. This understanding of harmony is often understood as implying the following moral principle:

An action is right just insofar as it promotes shared identity among people grounded on good-will; an act is wrong to the extent that it fails to do so and tends to encourage the opposites of division and ill-will. ${ }^{22}$

\footnotetext{
19 Tutu D. No future without forgiveness (London: Rider Random House, 1999: p. 63).

20 Mabovula N. "The erosion of African communal values: a reappraisal of the African Ubuntu philosophy", Inkanyiso: Journal of Humanities and Social Sciences 3 (2011): p. 41.

21 Tutu D. No future without forgiveness (London: Rider Random House, 1999); Gade C. "What is Ubuntu? Different Interpretations among South Africans of African Descent", South African Journal of Philosophy 31 (2012): 484-503; Murove MF. African Ethics: An Anthology of Comparative and Applied Ethics: University of Kwazulu-Natal Press, 2009); Shutte A. "Ubuntu as the African ethical vision," In: Murove MF, editor. African Ethics: An Anthology of Comparative and Applied Ethics: University of Kwazulu-Natal Press, 2009).

22 Metz T. "Toward an african moral theory", Journal of Political Philosophy 15 (2007): : p. 338.
} 
According to this principle, one ought to act in ways that enhance social harmony. In other words, the morally right action is the one that promotes positive relationships amongst individuals. In contrast, the morally wrong action is the one that promotes the opposite of harmony. That is, conflict, disharmony and negative emotions towards others, acts of bad-will if you like, are according to this view, morally wrong actions. John Mbiti makes a similar remark, "What is right is what connects people together; what separates people is wrong [causes ill-will or division]." ${ }^{23}$ Peter Kasenene expresses this differently, "in African societies, immorality is the word or deed which undermines fellowship." ${ }^{24}$ Afro-communitarians, therefore, consider that actions and emotions that bring people together are what are considered to be the moral ones. The rightness of an action is primarily determined by its promotion of social harmony and it can be balanced with other values. Note however the promotion of harmony cannot be done at any cost; for example, if the military intervention in a foreign country to avoid a genocide could cause even more deaths, then although it seems morally justified to intervene, this would not be acceptable from an Afro-communitarian perspective; for if the costs of achieving harmony are higher than the benefits of harmony, then the action should not be pursued. ${ }^{25}$

This has implications for the conception of moral status. According to this view, the relevant property for having moral status is the capacity to engage in communal relationships. The capacity to engage in communal relationships means, more precisely, to be able in principle to act on good-will towards others as well as being able to identify with others and have them relate to us in similar ways, too. ${ }^{26}$ Note here that this is a modal relational account of moral status, which is about the capability to relate in these ways, and not actual existing relationships. ${ }^{27}$ This capacity, however, is measured through individuals' harmonious or disharmonious actions, since the primary means (communal relationships) by which individuals gain moral status ontologically precedes moral status itself. In other words, it is partly through engaging in communal relationships in a positive way that one develops one's own capacity, and therefore, moral status is dependent on this. ${ }^{28}$ Additionally, the kind

\footnotetext{
23 Mbiti J. African Religion and Philosophy (Ibadan: Heinemann Educational Books, 1969: p. 2).

24 Kasenene P. Religious Ethics in Africa (Uganda: Fountain Publishers, 1998: p. 21).

25 Akiode O. "African Feminists Critique of Just Wars and the Reality of African Women in Wars," In: Cordeiro-Rodriques L, Singh D, editors., Comparative Just War Theory: An Introduction to International Perspectives (Maryland: Rowman \& Littlefield, 2019); Omotoso S. "African Womanist View of Just War Theory in Tunde Kelani's The Narrow Path", African notes: bulletin of the Institute of African Studies, University of Ibadan 42 (2018): 56-74; Cordeiro-Rodrigues L, Chimakonam JO. "The South African land question in light of Nelson Mandela's political thought", African Studies 79 (2020): 250-265.

26 Behrens KG. "A critique of the principle of 'respect for autonomy', grounded in African thought", Developing world bioethics 17 (2017): 126-134; Fayemi AK. "Personhood in a transhumanist context: An African perspective", Filosofia Theoretica: Journal of African Philosophy, Culture and Religions 7 (2018): 53-78.

27 Existing relationships do not determine the degree of moral status, but having relationships is, in part, what contributes to people developing virtues, which in turn, develops their moral status.

28 Behrens KG. "Two "Normative" Conceptions of Personhood", Quest: An African Journal of Philosophy 25 (2013): 141-162;Tutu D. No future without forgiveness (London: Rider Random House, 1999); Biko S. "Some African cultural concepts," In: Coetzee PH, Roux AJP, editors., Philosophy from Africa: a text with readings: Routledge, 1998); Etieyibo E, Chimakonan JO. "African Philosophy: Past, Present, and Future", Philosophia Africana 18 (2016): 1-7.
} 
of entity also determines the limits of moral status that the entity can have. As Metz clarifies, an entity that does not have this capability would be an entity or a thing that is, say, genetically unable to identify with others or that cannot be better or worse off (for example, a stone or a writing pen). ${ }^{29}$ Such entities are constitutionally unable to commune with others, nor can they be communed with.

Furthermore, according to a modal view or relational theory of moral status, there can be several degrees of moral status, with an individual having either a full or partial moral status, depending on its capacities for communal relationships. The more one is capable of engaging in communal relationships with other individuals, the higher the moral status (and by extension, the greater the ethical obligation to such beings). Additionally, the fullness or partiality of moral status is also dependent on the idea that entities can either be subject, object, or both, in a relationship. Someone who can be a subject and an object has full moral status, whereas an individual that is simply an object has partial moral status. To be the subject in a relationship means having the capacity to identify and exhibit good-will towards others. That is, someone is a subject if she can think of herself as a 'we' with others, share ends with them, sympathize with them, and act for others' sake. Hence, not being a subject in a relationship means lacking the ability to conceptualize or act emotionally in a communal relationship. To be an object in a relationship means being able to be communed with, by others. That is, to be simply an object here means that others can identify with, sympathize with, and act in good-will towards the object. Most adults with standard capacities satisfy the conditions of full moral status, and are more morally considerable than other entities that can only be communed with, by others. These include infants, embryos, foetuses, and animals. In subsequent sections, this article describes the ways these entities are said to have moral status.

To clarify, this perspective it is worth contrasting the Afro-communitarian relational approach from western relational approaches such as Ethics of Care. Specifically, unlike Nel Noddings's Ethics of Care, the Afro-communitarian relational approach requires a combination of identifying and exhibiting solidarity with others. For Noddings, an entity has moral status insofar as it responds to the caring attitude of the caring person. ${ }^{30}$ This implies that those who cannot respond lack moral status, including those we intuitively believe have moral status of some sort such as animals, and Alzheimer patients who suffer from advanced neurodegenerative conditions. Some western accounts of moral status such respect-based account of Kantian ethics and contractualism also have a similar weakness. Based on these approaches that ground moral status in intrinsic factors, entities have moral status to the extent that they are rational (Kantian ethics) or engage in mutual accountability (contractualism). Accurately, based on these approaches, what counts is whether an entity has the feature in question, such that those who lack rationality such as embryos, foetuses and infants, or cannot engage in mutual accountability - like animals - lack moral status. Contrastingly, the Afro-communitarian relational theory does a better

\footnotetext{
29 Metz T. "An African Theory of Moral Status: A Relational Alternative to Individualism and Holism", Ethical Theory and Moral Practice 15 (2012): 387-402.

30 Noddings N. Caring (Berkeley: University of California Press, 1984).
} 
job accounting for the intuition that entities we believe have moral status, do in fact, have it, and in what ways for the above intuition, by grounding moral status in the capacity to relate communally. Given these limitations that Western approaches present, we believe that the perspective presented in this paper inspired in Afro-communitarian philosophy can offer a competing alternative worth of consideration to address not just the rationing issue we deal here, but also other moral issues.

\section{Implications for Rationing in the Context of Pandemic}

The aforementioned theory provides guidance for supplementing current discussions on the rationing of scarce medical resources in the context of a pandemic. Particularly, it offers both instrumental and moral desert reasons for rationing decisions. In terms of instrumental reasons, what matters most when making decisions is how a certain action or certain individuals involved can be first, instrumentally valuable for the promotion of social harmony, i.e., offering a positive friendly-like relation amongst individuals in society. Furthermore, whatever distribution pattern is used, it should be one that is not understood as unfair, as this may create social disharmony. For instance, extensive inequalities and exploitation tend to be divisive and alienating; thus, if distribution patterns are perceived as unjust and particularly if they are based on significant economic inequalities, then they will promote social disharmony.

Regarding reasons based on moral status, those individuals with a higher moral status, i.e., those who can fully engage in the aforementioned positive relationships should be given priority to medical treatment. In other words, individuals with instrumental value ought to be prioritized in receiving medical treatment because they have the capacity to prevent social disharmony. There is also a higher obligation - though not to a degree comparable with those of instrumental value - and that is to prioritize those who can commune or be communed with over those who only have partial moral status (i.e., that can only be objects of communion). The individuals with higher moral status are those that have this capacity and, other things being equal, any adult human with standard human capacities; that is, broadly speaking, an average individual also has this capacity for engaging in social harmonious relationships and, thereby, being both subject and object of communion.

Rationing involves painful decisions to prioritize, which might be difficult from a respect-based perspective, since what matters is whether individuals have the power in question. All those who meet the sufficiency condition, have equal moral status. A benefit of appealing to a gradational theory of moral status is that it offers a better justification of, what, if any, varying ways individuals can be subjects of direct duties. An adult, however, may decline to be prioritized over his/her daughter, whose status is qualitatively and significantly less than that had by adults. The communal character of Afro-communitarianism does not wipe away the individuality of each person, or imply that individual choices and decisions may be subordinated. As Mbiti says, "Whatever happens to the individual happens to the whole group, and 
whatever happens to the whole group happens to the individual." 31 The prioritization ought to be understood as an entitlement individuals have, but which they are free to abdicate if they so wish.

In addition, this theory also implies that those who lack capacity or are still in the developing stages of capacity have a lower moral status and, therefore, are entitled to less. Those who lack capacity include sociopaths and psychopaths and those with mental disorders which are substantial in creating individuals incapable of being emotionally and behaviorally driven as subjects towards objects of communion. Other neurodegenerative conditions such as advanced dementia also put one at risk of losing one's capacity to be the subject of communion. Embryo, foetus and infants $^{32}$ are prime example of individuals who are in the stages of developing this capacity and, therefore, are also less entitled and ought not to be given priority. All these individuals can be communed with, but they are either not fully able to be subjects or are only partially able to be subjects of communion. However, others may be emotionally and cognitively driven towards them, hence they have partial moral status. The theory requires agents to honor individuals to the extent that they can be both subject and object of communal relationships.

The theory also implies that there are differences amongst individuals with full moral status in terms of their entitlement to medical treatment when this needs to be rationed. In particular, those individuals who can be instrumentally crucial for the development of social harmony in society or have demonstrated a history of engaging in such relationships will be entitled to more than others. Illness can inhibit one's capacity to relate as true subjects. The reality of relationality in Afro-communitarianism, as Felix Murove observes is that as humans we depend on other human beings such as health professionals in a time of health crisis, who are uniquely placed to render such service, to achieve health and wellness. ${ }^{33}$ Those with a higher capacity and history tend to be, according to the African view, older, although this is not always necessarily the case. To understand this, note that African philosophy gives high importance to virtue. In particular, African philosophy tends to value character properties such as benevolence, generosity, honesty and so forth. These virtues, which are some of the ones relevant for the degree of moral status as they improve the capability to positively relate to others, are acquired with experience, which usually comes with age. Much virtue requires trial and error, experience, and moral learning. In fact, in the African conception of the person there is an ontological progression from birth to death; an individual is not a full person when one is born, rather personhood is something that is acquired through time, so the older one gets, the more likely it is that one has acquired more personhood. Individuals with age acquire social responsibilities and gain moral maturity. ${ }^{34}$ This moral maturity makes them more fit and likely to act in morally right ways, but also because to learn

\footnotetext{
31 Mbiti J. African Religion and Philosophy (Ibadan: Heinemann Educational Books, 1969: p. 108).

32 Some infants may potentially have this capacity fully developed, but this is rare..

33 Murove MF. "Ubuntu", Diogenes 59 (2012): 36-47.

34 Menkiti I. "Person and Community in African Traditional Thought," In: Wright R, editor. African Philosophy, an Introduction. 3rd (Lanham, MD: University Press of America, 1984).
} 
virtue, one needs examples and people who acquire it over time, then they became moral guiders of the community. Hence, the loss of an older person tends to be more problematic because they have the knowledge needed for society and are the moral examples necessary, in this way, others can see and acquire moral learning themselves. ${ }^{35}$ As an example, while describing the central beliefs of the Akamba people of East Africa, John Kilner remarks that they (the Akamba people) believe that the "older a person becomes, the more intricately interwoven that person becomes in the lives of others, and the greater the damage done if that person is removed." 36 Given that acting morally is related to the learning of virtues, the older one gets the more likely it is that one has acquired those virtues that confer moral status.

It is not always the case that those who are instrumentally valuable for social harmony necessarily need to be older; or need to be those with higher moral status. To recall, resources ought to be used in ways that promote cooperation and sociability and enhance relational capacities. In some situations, this may mean valuing individuals who have specific functions in communities, those are instrumental in keeping social harmony. The success of the response and the good of society depends substantially on allocating scarce resources to those who are essential at fighting the COVID-19 pandemic. Based on the preceding, it is right to say that in prioritizing individuals with instrumental value, a modal relational approach to moral status is in fact, expressing its preference for communal relationship, which is the basis of moral status itself. In particular, there is a greater obligation to promote harmony and communal relationships, which might imply in the case of a pandemic, prioritizing health professionals, frontline workers, first responders and other essential professionals whose skills and capabilities are crucial for the continuation of society. It is not against medical professionalism to prioritize these ones in a time of public emergency; rather the intuition here is that health professionals cannot save lives or address illness that undermines individual's capacity to relate at all if they are dead.

Based on the importance of harmony, individuals with a high cultural capital in a specific society may also be included so that they can positively influence others to follow the norms of social distancing and so forth. It would also mean prioritizing the care of those whose services are essential for maintaining peace and security. These include law enforcement agents, security service personnel, the national guard, transport, and communication workers, to name a few essential personnel. Instrumental-based rationing is ethical only if essential personnel are able to recover in time to be useful for communion. Summarily, the goal of an instrumental-valued based system that aligns with the relational theory of moral status in a time of public health crisis should be to save the lives of individuals who can, in turn, save other lives. Thus, it becomes apparent that this rule does not imply that the lives of the

\footnotetext{
35 Some African scholars disagree. For example, Bernard Matolino has a different opinion about this, and there has also been a counter-refutation by Polycarp Ikuenobe. See Matolino B. "The (mal)function of "it" in Ifeanyi Menkiti's normative account of person", African studies quarterly: the online journal of African studies 12 (2011): 23-37; Ikuenobe P. "Matolino's misunderstanding of Menkiti's African moral view of the person and community", South African Journal of Philosophy 36 (2017): 553-567..

36 Kilner JF. "Who Shall Be Saved? An African Answer", Hastings Center Report 14 (1984): : p. 19.
} 
instrumental agents are more valuable than other lives but instead derives more from the more profound obligation to promote communal relationships.

Given the preceding paragraph, one way of honoring the mode through which individuals gain capacity is prioritizing those whose capabilities and skills are vital for the existence and maintenance of social harmony. This is consistent with rationing based on instrumental value. One has instrumental value if one's skills are crucial to the continued existence or well-being of the society during a public emergency. To this end, rationing medical resources based on instrumental value is ethical for preventing disharmony or social disintegration. This would imply prioritizing frontline healthcare workers, whose essential services are vital for overall social harmony.

\section{Moral Challenges to the Relational Perspective}

The previous section outlines the theory that we defend regarding the Afro-communitarian perspective on rationing. In this section, we would like to reinforce the arguments in favour of the theory by looking at how it responds to some possible objections. Through looking at these objections, we hope to sufficiently demonstrate that there is a solid moral case to endorse it. Particularly, in this section, we would like to respond to potential criticisms that the implications of the relational perspective on rationing have morally troubling implications. One line of objection that can be raised against our view is that it implies some form of inegalitarianism. In particular, critics may argue that a theory of moral status which prioritizes based on one's capacity to commune and to be communed with, would lead to ableism, to the extent that it contributes towards a further devaluation of individuals with disabilities. Based on the relational theory of moral status, individuals who suffer specific disabilities that render them incapable of being subjects of communal relationships will more likely be treated in ways that are less than human. A rationing theory based on capacity will thus constitute an obstacle to equal opportunity and full participation in society for those individuals with disabilities.

Another objection that critics may raise is that a theory of prioritization grounded in the modal account of the relational theory of moral status generally favors older adults at the expense of the younger. Critics may point out that the most important factor in this gradational approach to rationing is the capacity to be both subject and object of relationships, which appears to increase as the individual advances in years. This would imply that older adults would normally receive priority in the distribution of limited medical goods. One of the reasons why this implication is problematic is because while the theory of moral status prevents discrimination against older adults, it encourages discrimination against younger individuals.

Alternatively, an objection could be raised that the life-phased approach, which is one of the leading rationing approaches, not only does not have a problem with age discrimination, but also holds a view that is more morally intuitive. According to the life-phased approach, rationing decisions ought to be guided by the entitlement to a natural lifespan. The starting point is that all individuals are entitled to have the opportunity to achieve life's possibilities (love, beauty, travel, etc.,). Thus a 
natural lifespan is one in which "life's possibilities have on the whole been achieved after which death may be understood as a sad but nonetheless relatively acceptable event". 37 The natural lifespan theory imposes duties on governments and others to help individuals live out a natural lifespan. ${ }^{38}$ To this end, there is a collective social obligation to develop and pay for those services and medical technologies deemed necessary for serving the end of a natural and fitting life; and after that, palliative, rather than life-extending, purposes.

The proponents of this theory reject that this perspective is ageist, although it clearly prioritizes the young. Indeed, they argue that the lifespan theory is consistent with equal respect for young and old. To make this point, Callahan appeals to a reasonable/prudential person's standard. ${ }^{39}$ Callahan argues that if a prudent individual were given the responsibility of allocating limited resources across his life years, s/he would allocate more significant resources to the younger period in exchange for fewer ones in old age. ${ }^{40}$ They contend that the theory is not ageist because it gives everyone the same opportunity to have a fair share of life. The natural lifespan theory of distribution requires that younger people ought to be prioritized in the case of rationing because they should have an equal opportunity to experience all lifespans. The young and the old both share the common fates of illness and death, which increase gradually over the years. Additionally, both the young and old mutually bear the social responsibility of helping each other cope with these common fates and prevent premature death. Good healthcare services are essential for fulfilling these responsibilities. However, the elderly hold a disproportionate share of the healthcare system, since they (the elderly) generally make more demands on the same. This could be disproportionality counterbalanced by prioritizing younger folks, who are yet to reach their natural lifespan. ${ }^{41}$ If the young are to flourish, society must be willing to prioritize this group. To this end, rationing based on life-years lived or age is not mean-spirited or utilitarian but egalitarian and affirmative of old age. The disadvantages imposed at old age are counterbalanced by the advantages of earlier years. ${ }^{42}$ The young should know that their old years will be marked by the

\footnotetext{
37 Johnson PR. "Allocation and aging: a review and response to Callahan's Setting Limits", The Linacre quarterly 55 (1988): : p. 60.

38 Callahan D. "Must we ration health care for the elderly?", The Journal of law, medicine \& ethics: a journal of the American Society of Law, Medicine \& Ethics 40 (2012): 10-16.

39 Callahan D. Setting Limits: Medical Goals in an Aging Society (New York: Simon and Schuster, 1987); Callahan D. "Must we ration health care for the elderly?", The Journal of law, medicine \& ethics: a journal of the American Society of Law, Medicine \& Ethics 40 (2012): 10-16.

40 Callahan D. Setting Limits: Medical Goals in an Aging Society (New York: Simon and Schuster, 1987); Callahan D. "Must we ration health care for the elderly?", The Journal of law, medicine \& ethics: a journal of the American Society of Law, Medicine \& Ethics 40 (2012): 10-16.

41 Callahan D. "Must we ration health care for the elderly?", The Journal of law, medicine \& ethics: a journal of the American Society of Law, Medicine \& Ethics 40 (2012): 10-16.

42 Jecker NS. "African Conceptions of Age-Based Moral Standing: Anchoring Values to Regional Realities", The Hastings Center report 50 (2020): 35-43; Reese PP, Caplan AL, Bloom RD, Abt PL, Karlawish JH. "How should we use age to ration health care? Lessons from the case of kidney transplantation", Journal of the American Geriatrics Society 58 (2010): 1980-1986.
} 
same limitations which older adults now experience. Over time, everyone experiences the same fate.

Ruth Tallmann offers a more nuanced form of this theory. ${ }^{43}$ In Tallmann's opinion, "priority should be given to those who are in the midst of their life projects (such as young adults over those who have not yet begun their characteristically human lives (such as the very young)." 44 Tallmann adds that there are two core constituents of a complete life: "it is one in which a person has carried her goals and projects to fruition, and b) it is one that lasts long enough for its owner to have the opportunity for the range of experiences normal for a human being." 45 Therefore, those in the younger years of their lives have had the least opportunity to experience more life stages typical of human life and should receive higher priority in the context of resource rationing. One may consider the example of hotel guests who overstay their time at a hotel, and are promptly asked to leave the property for arriving guests; or individuals who overstay their time at a bar, having had their fill, and are promptly asked to leave to allow room for new customers.

Alternatively, rather than an egalitarian-based argument, the same conclusion can be taken from a utilitarian point of view, defending that there is an ethical obligation to save more years of life than fewer. The quality-adjusted life-years (QALYs) or the life years from transplant (LYFT) approach to rationing scarce organs in the field of transplantation are examples of utilitarian-based reasoning. The American Medical Association endorses the rationing of finite resources that promotes the "greatest duration of benefit after recovery." 46 The justification for utilitarian-based reasoning is that it is morally preferable to save more life-years than fewer to maximize the overall benefits of limited medical resources.

Another related problem with the relational theory of moral status is that it seems to imply that if someone has a lower life expectancy, s/he should be saved if they meet the condition of full moral status. Given utilitarian considerations, one ought to save more life-years than fewer. This implies saving individuals with higher life expectancies (which include more life years and life quality) than individuals with limited life expectancies owing to comorbidities. This obligation deepens as life expectancy increases. Contrarily, the relational theory implies that in some situations, even those who benefit the least (e.g., because they are unlikely to survive) ought to be given priority over those who benefit the most. This is particularly a problem for the relational view because older seems to demand a higher moral status than younger, and age itself is a risk factor for many human diseases and quality of life. Conditions, as Jeckers observe, that "strike at old age tend....to be chronic.....progressive and disabling, resulting in dependency and reduced quality

\footnotetext{
43 Tallman R. "Valuing lives and allocating resources: a defense of the modified youngest first principle of scarce resource distribution", Bioethics 28 (2014): Ibid.

44 Tallman R. "Valuing lives and allocating resources: a defense of the modified youngest first principle of scarce resource distribution", Bioethics 28 (2014): 207-213.

45 Tallman R. "Valuing lives and allocating resources: a defense of the modified youngest first principle of scarce resource distribution", Bioethics 28 (2014): p. 208.

46 Singh JA, Moodley K. "Critical care triaging in the shadow of COVID-19: Ethics considerations", South African Medical Journal 110 (2020): p. 358.
} 
of life." ${ }^{47}$ Thus, saving older adults with fewer life-years may create grave problems for the economy, increasing the government's healthcare expenditure, thus making it extremely difficult for governments to create other worthy social programs that might promote social harmony. Contrarily, saving more life years is still a vital strategy for future economic development (after a pandemic); through the direct labor productivity effect (where individuals with more life years have higher returns to labor input), and through the indirect incentive effect (where individuals with a higher life expectancy have the incentive to invest in education as the time horizon over which returns can be earned).

The objections mentioned above can be classified as either contending that alternative theories ought to be preferred or that the relational perspective we defend has morally unacceptable implications. The replies to these objections can be of three kinds; replies that demonstrate the limits of the other approaches; replies that show the superiority of our perspective; replies that counter-argue that some of those unacceptable implications apply to our argument. The theories that rely on saving those most likely to benefit and, in particular, the healthy, have inegalitarian implications that aggravate current socio-economic inequalities. Research suggests that as a result of poverty, geographical location, lack of access to education, and so forth, working-class and racialized minorities (blacks and Latinos, especially) tend to have a higher degree of respiratory disease, heart disease, and cancer. This is often because socially excluded and economically vulnerable groups tend to live in places with few options of where to buy food (often there are only small shops with little on offer alongside fast-food chains, such as MacDonald's), and live near garbage dumps, industrial areas and animal farms, which contaminate the water and air, and contribute significantly to the aforementioned diseases. ${ }^{48}$ This entails that actually, the criterion of saving the healthy has two problematic implications. Firstly, it aggravates already existing inequalities, reinforcing the socio-economic differences already embedded in society. Secondly, it implies, albeit indirectly, something that most people reject as counter-intuitively wrong: that socio-economic status is what determines if someone receives health treatment. It does not affirm so directly, but indirectly it does due to the correlation between good health and economic status.

The theories that give preference to the young on egalitarian grounds fail to be egalitarian because it is not the case that all elders have had the same opportunities for living a good life. A significant number of elderly black adults in South Africa lived most of their lives under apartheid regimes. ${ }^{49}$ The arguments for opportunities do not apply to them since they have had little chance to enjoy the advantages that others enjoyed earlier in life. Again, given the recent history of classism, racism and

\footnotetext{
47 Jecker NS. "Age-related inequalities in health and healthcare: the life stages approach", Developing world bioethics) (2017): 1-12.

48 Harper B. "Doing Veganism Differently: Racialized Trauma and the Personal Journey Towards Vegan Healing," In: Hayes-Conroy, editor. Doing Nutrition Differently: Critical Approaches to Diet and Dietary Intervention (London: Routledge, 2016); Pellow DN. "Environmental Inequality Formation:Toward a Theory of Environmental Injustice", American Behavioral Scientist 43 (2000): 581-601.

49 Wareham CS. "Youngest first? Why it is wrong to discriminate against the elderly in healthcare", South African Journal of Bioethics and Law 8 (2015): $37+$.
} 
sexism, then it seems that this theory is privileging white bourgeoise males. Also, rationing based on opportunities, as pointed out by Douglas White and colleagues, ${ }^{50}$ would be extremely difficult to apply in the event of a pandemic owing to the complexity of measuring the relevant attributes.

Moreover, the age factor ignores the luck factor as an important variable here. COVID-19 infection and ill-health may be a result of unforeseeable and unpreventable outcomes often described as brute bad luck. ${ }^{51}$ A pandemic qualifies as a paradigmatic instance of brute bad luck. For example, an elder may get infected as the result of bad choices made by younger people who were socializing with them. When it is a product of choice, individuals should typically be held responsible for the harm they suffer on account of their uncoerced decisions. Others should not be made to pay for the irresponsible decisions of individuals. In this regard, knowledge about one's abuse of cigarettes should inform decisions as to whether a younger smoker or an elderly non-smoker adult should get the lungs available. Contrarily, society ought to aid those who suffer brute bad luck or are unable to defend their interests and needs against unavoidable catastrophes. The failure of a society to rescue those who suffer on account of brute bad luck is a failure to honor an individual's moral status or act in ways that dignify them.

Moving now to the point of whether alternative theories ought to be preferred (i.e., those that affirm that one ought to save the young, the healthy or the many), consider the following thought experiment. Imagine that there are two patients and only one can be saved; one is a young, healthy Adolf Hitler who is very likely to live, and the other is an older Martin Luther King Jr. who has a severe medical condition, making him less likely to survive. Hitler, if saved, will then gain strength to carry out his Nazi ambitions and the Holocaust; we can tell this because at this point, Hitler has already demonstrated his hatred for the Jews and his ambitions to rule Germany. Contrastingly, Luther King Jr. has shown his sense of goodwill and sacrifice for the community and is preparing to make a speech that will inspire many to pursue racial justice in a pacifist manner. It seems unjustifiable to save Hitler, not just because of his character but also because of the cost-benefit analysis for the future of a society where one can predict what will happen if one saves Hitler but not Luther King Jr. Now imagine the same situation, but the option is to save ten young, healthy members of the SS or Luther King Jr. Likewise, most people would be inclined to save Luther King Jr. due to his past and future contributions to society as well as his moral character. What this thought experiment demonstrates is not that health, age, and quantity of lives saved are not relevant; instead it shows that they are of secondary importance when compared to the criterion we offer. Surely in a possible world where you have ten young and healthy copies of Martin Luther King

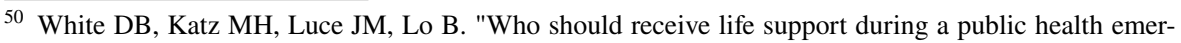
gency? Using ethical principles to improve allocation decisions", Annals of internal medicine 150 (2009): 132-138.

${ }^{51}$ Jecker NS. "Age-related inequalities in health and healthcare: the life stages approach", Developing world bioethics) (2017): p. 2.
} 
Jr. and one old and unhealthy Martin Luther King Jr. saving the ten would be better than saving the one.

This argument shows that moral character is more important than other factors, but it does not show that our particular conception of what it is to be moral is the necessary one to follow. We do not wish to give a complete account here of why the relational principle ought to be endorsed, for this requires a different article that is outside the scope of the current purpose. However, we wish to give at least two replies. Firstly, the principle, at least in the Southern African and Confucian context, is intuitively justified as true and this suggests that at least there it would be unnecessary to justify. ${ }^{52}$ Put differently, the value of intuitions is measured in part by the quantity of reasonable people who agree to them, and there is a large number of people who would share the same intuition. ${ }^{53}$

Secondly, those who are committed to the idea that health professionals are entitled to priority in treatment may also be committed to our perspective. Most people consider it as the case that health professionals are entitled to priority treatment for the benefits they can bring to society, it is a matter of reciprocity given the sacrifice they offered to the community. ${ }^{54}$ Equally, our perspective is based on promoting positive social outcomes in society and giving more to those with moral merit; the difference is that we do not think it is only the moral merit available during a pandemic that matters, but the contribution to society as a whole.

The third line of response is that either our argument does not have some of the negative implications laid out by the objections or it implies inequalities which are morally justified. Against the argument that our view is ageist, note the following points. Firstly, our argument does not state that elders ought to receive priority. Instead, because we recognize that moral progression takes time, someone who is older is more likely to have progressed more, but this is not necessary. Moral progress can be carried out in many ways; one can morally progress by the way one lives, by reading and forming opinions about ethics and so forth. Therefore, it can develop earlier or later, depending on the person. ${ }^{55}$ Secondly, our argument implies that people with certain neurodegenerative diseases that tend to come with age, such as dementia, are not prioritized. Moreover, according to the view we defend, a vicious elder person (e.g., an elder white supremacist) does not have priority of treatment over a younger virtuous one. Hence, we clearly state that some older people are less entitled because they have lost their capacity for communion. It also does not save virtuous elders at any cost; if saving only the elders can lead to a

\footnotetext{
52 Bell DA, Metz T. "Confucianism and ubuntu: Reflections on a dialogue between chinese and african traditions", Journal of Chinese Philosophy 38 (2011): 78-95.

53 Sidgwick H. Methods of Ethics (Indianapolis: Hackett Publishing Co., 1981).

54 Farrell TW, Francis L, Brown T, et al. "Rationing Limited Health Care Resources in the COVID-19 Era and Beyond: Ethical Considerations Regarding Older Adults", (2020); White DB, Lo B. "A Framework for Rationing Ventilators and Critical Care Beds During the COVID-19 Pandemic", Jama 323 (2020): 1773-1774.

55 Wareham CS. "A Duty to Explore African Ethics?", Ethical Theory and Moral Practice 20 (2017): 857-872.
} 
significant negative impact on the economy, which will, in turn, lead to social disharmony, this option is not preferred.

Regarding ableism, note that not all disabilities imply someone has a lower moral status; only those that undermine the capacity to commune. The physically disabled, for example, are not included in this theory. We, however, fully accept that it is an implication of our theory that some disabled individuals have a lower moral status. Nevertheless, we do not think this is problematic. The theory is hierarchical in certain ways, but not all hierarchies or inequalities are bad; what matters is whether there is an underlying good moral justification for the inequality. ${ }^{56}$ As Wang Pei and Daniel Bell state, 'the choice today is not between a society with no hierarchies and one with hierarchies, but rather between a society with unjust hierarchies that perpetuate unjust power structures and one with just hierarchies that serve morally desirable purposes. ${ }^{57}$ In short, inequalities may be justified when these actually bring benefits to everyone, including the ones who are treated unequally. ${ }^{58}$ Similarly to what John Rawls states, inequality can be justified if this inequality is instrumental in improving the situation of the worst off. ${ }^{59}$ More precisely, although Rawls considers that a just arrangement requires that the arrangement of the institutions of a society's basic structure (the political constitution, the legal system, the economy, the family, and other key institutions) ought to provide an equal set of basic rights and opportunities, his second principle of justice admits some inequalities. Namely, the second principle of justice is:

Social and economic inequalities are to satisfy two conditions: first, they are to be attached to offices and positions open to all under conditions of fair equality of opportunity; and second, they are to be to the greatest benefit of the leastadvantaged members of society (the difference principle). ${ }^{60}$

The second part of the second principle of justice does not say how wealth and income should be distributed; it suggests that inequalities are to be distributed equally, but if unequal distribution would be to everyone's advantage, then this is accepted and indeed morally required. Imagine, for example, that inequalities of wealth and income can lead to higher wages to everyone and a better social security system. In this case, the Rawls's principle allows inequalities, so long as these will benefit everyone. Although we do not aim here to defend Rawls's theory of justice, the point he makes is a solid one, which is that hierarchies or differential treatment may potentially be for everyone's benefit and in that case they are morally justified. Likewise, in our argument, the point is that the skillful and the virtuous are more likely to play fair and use their skills to benefit the disabled as well.

\footnotetext{
56 Scanlon TM. Why Does Inequaliy Matter? (Oxford: OUP, 2018).

57 Bell DA, Pei W. Just Hierarchy: Why Social Hierarchies Matter in China and the Rest of the World (New Jersey: Princeton University Press, 2020: p. 31.

58 Scanlon TM. Why Does Inequaliy Matter? (Oxford: OUP, 2018).

59 Rawls J. A Theory of Justice (Cambridge: Harvard University Press, 1999).

${ }^{60}$ Rawls J. John Rawls Justice as Fairness: A Restatement (London: Harvard University Press, 2001: p. 42f).
} 


\section{Impracticability, Authoritarianism and Privacy}

One line of objection to the relational view is that it is not practical in real-life situations. In a situation of a pandemic, guidelines must be simple enough to apply in ways that overcome the challenges associated with rationing. There will be insufficient time for complex algorithms during a health crisis. Thus, critics may also argue that the theory of rationing which this study advances is not actionguiding and might not be a useful theory for addressing dilemmas regarding prioritization. One problem is that a health professional cannot know whether a person has full or partial moral status. This information is not publicly available, and it is only those in close relationships with the person who may be able to know this. The other reason why the perspective we offer can be classified as impractical is because it does not offer guidance regarding how to decide who to give medical attention to. That is, seeing that those who are similar in ethically relevant ways are not treated differently when medical needs exceed available medical resources. For example, if two individuals who satisfy the requirement of full moral status require the only available ventilator, how does the health professional determine who receives the ventilator? Moreover, even assuming all these practicability problems were solved and the relevant information was publicly available, it seems to imply that much of individuals' personal life is shared, which is a violation of personal privacy. Particularly, it seems that it would involve some kind of moral credit system or similar, which would not only involve sharing too much personal information but could be an instrument of power used by governments to punish individuals as they wished.

In reply to the impracticability questions, note that our main aim is to set the principle for rationing and not to explain how the technical details would implement it. This latter question is a matter which requires technological detail that does not necessarily lie within the scope of this article. Furthermore, the question of practicability does not challenge the principle itself and only raises problems of implementation which are technical, not philosophical. However, note that there are a variety of indicators that are already used in current societies to evaluate how much someone gives to communities that can be included and are not controversial; this is particularly the case, if the person pays or evades taxes, how much have they contributed to charities by volunteering or if they have a criminal record related to heinous crimes (like paedophilia or terrorism). This system seems intuitive and is already in use for other things, such as selection for certain jobs, bank loans, and so forth. Doctors will have to work with imperfect information (as they normally do), but this is also the case about other decisions on health, when information is not fully available to doctors. These moral contributions to the information can be made available to a similar degree by updating them in a similar informatic system as the health one. For example, smart cards (customarily used for national identity cards) and which only contain the information within them and nowhere else could be a relatively safe way to carry this out. To the question about people with similar moral status, the next step is to use other criteria, such as health, age, and so forth. If there is tension between moral 
status and the past in promoting communal relationships, the latter ought to be prioritized. This is because the engagement in communal relationships precedes moral status itself, and is one of the primary means for developing moral status. Hence, decisions on rationing regarding individuals who are not different in ethically relevant ways should be based on one's previous contributions. If there is still no way to differentiate between people here, it is acceptable to use the other common criteria, such as their likelihood to survive.

To reply to the authoritarianism and privacy problems, note that in a time of a pandemic the requirement of privacy is less strong; privacy needs to be balanced with both the value of life and quality of life, and in the situation of a pandemic, it may be justifiable to ignore privacy so that the other two values are fulfilled. In fact, most countries are already violating confidentiality and privacy on the grounds of saving lives. Notably, this is often the case in contagious diseases where, for public health reasons, privacy is violated. ${ }^{61}$ Secondly, we recognize the risk of authoritarian regimes imposing their morality on the public is real. However, we note that it naive to think that health records do not impose similar problems. Medicine is not in itself an apolitical entity; rather, it relates to the beliefs of its time and has political goals. ${ }^{62}$ Insane asylums, as demonstrated by Michel Foucault, appeared as a form of punishment for those who did not want to submit to the labour laws of the time. ${ }^{63}$ HIV testing was used to persecute and scapegoat homosexuals. Our proposal would not change the way people are treated in authoritarian regimes; for in an authoritarian regime, the way resources are distributed are unfairly prioritized, with politicaldriven punishments and people controlled in many ways. Policies do not work for every political system and they may have different applications, depending on the kind of legal protections citizens have against their governments. For example, a country may request everyone to test for HIV and may do so to prevent an HIV pandemic and offer healthcare, or it may do so to exclude certain social groups or even murder those who have the disease. Hence, certain laws only work if the regime is already one that is democratic to a certain extent. Thus, our prescription only works as a protection from authoritarianism in an already non-authoritarian society, and would not work in other societies.

\section{Conclusion}

Most decisions to offer rationing within the context of a health emergency may save some lives but come at the expense of other lives. Evidently, there is an imperative to address the conditions necessitating prioritization during health emergencies and articulate clear solutions for overcoming the same. This current study has outlined some useful rules of thumb for distributing scarce health resources during a

\footnotetext{
61 Sulmasy DP, Veatch RM. "Should Institutions Disclose the Names of Employees with Covid-19?", Hastings Center Report 50 (2020): 25-27.

62 Foucault M. Madness and Civilization (New York: Vintage Books, 2006).

${ }^{63}$ Foucault M. Madness and Civilization (New York: Vintage Books, 2006).
} 
pandemic. Specifically, the study argues that there is a greater obligation to aid those who have moral status and who have contributed to social harmony over those who do not have moral status or have promoted disharmony. This, we contend, is a superior approach to rationing than the life-phase approaches that are often used. Further research should try to apply this rationing theory to other ethical decisions that involve life and death, such as war, euthanasia and abortion.

Acknowledgements We would like to thank Thaddeus Metz and the two anonymous reviewers for their very helpful comments.

Funding Luís Cordeiro-Rodrigues's research has been funded by Hunan University's Fundamental Research Funds for the Central Universities, fund number 531118010426. 本 文受湖南大学“中央高校 基本科㸴业务费”专项资金资助 (531118010426).

Publisher's Note Springer Nature remains neutral with regard to jurisdictional claims in published maps and institutional affiliations. 